\title{
CULTURE AS A PRODUCT: ISSUES OF BENGALI ETHNICITY IN NORTH-EAST INDIA
}

\author{
Nidhu Kumar Dhar \\ Lecturer, Department of English \\ Radhamadhab College, Silchar, Assam, India
}

\begin{abstract}
Considered as a set of beliefs, values, social forms and material traits, culture is organised by an ideology. Ideology is the intellectual dimension of culture which has been famously referred to by Marx as "false consciousness" which justifies the power of the ruling class. However, Louis Althusser takes a different stance, for he argues for a materialist understanding of ideology. Rather than considering ideology as mistaken ideas about the world, for him, ideology is essentially practical, which does not simply exist in the 'world of ideas' conceived as a 'spiritual world'. He believes that it exists in institutions and the practices specific to them. The theory of Cultural Materialism (emerged as an expansion of Marxist materialism) explains cultural organisation which is shaped by ideology within a materialistic framework. Unlike Marxist theory, cultural materialism views both productive (economic) and reproductive (demographic) forces as primary factors that shape society. Cultural materialists view society as being operated by the process of production and reproduction and this becomes the driving force behind all cultural development. Therefore, the systems like government, religion, kinship etc., are considered to be constructs that only exists for the purpose of promoting production and reproduction. It is in this context that the multi ethnic, multi lingual and multicultural construct of North East India deserves special attention in critical discourse. The paper attempts at situating the North East India in these theoretical paradigms and study them in the broader context of 'Look/Act East Policy'. Considering above theoretical perspectives, the paper shall try to look at the ethnic cultures of North East region and how due to globalisation ethnic cultures are irrevocably converging for the sake of production and reproduction, thus losing their ethnic identity and uniqueness.
\end{abstract}

Keywords - Culture, Ideology, Materialism, Ethnicity, Production, Reproduction.

\section{INTRODUCTION}

Culture, as a multidimensional phenomenon, is difficult to define. However, it is widely considered as the sum of way of life, including expected behaviour, belief, values, social forms, and language and living practices shared by members of a society. Culture is manifested in the ways an individual and especially a group of people live, think, feel, organize, celebrate and share life. These are further marked by languages, gestures, symbols, rituals, lifestyle and relations which inclusively govern the life, thinking and the actions of people. Culture also manifests itself through festivals, food habits, dress, and celebration which give the group a common identity. Moreover, it is culture that produces the kind of literature, music, dance, architecture and various other art forms as well as many organizations and structures that make the functioning of the society smooth and well-ordered. Traditional ideas and attached values lie at the core of culture which is organized and given cohesion by 'ideology', for cultural systems are conditioned by past action and it goes on to condition future action. Ideology motivates or rationalizes adhesive beliefs and values that have been transmitted from generation to generation. Ideology is not only belief but it is the intellectual dimension of belief systems, for it legitimizes the norms, beliefs and values as normal or standard and also shapes culture or affect cultural change. In order to comprehend more about how ideology organize or fabricate culture, it becomes pertinent to bring Marxist theories. Although the concept of ideology did not originate in Marxism, yet it is evidently an important concept in almost all Marxist thinking about culture. Marx "argues that all mental (ideological) systems are the products of real social and economic existence. The material interests of the dominant social class determine how people see human existence, individual and collective" (Selden, p. 24). The material interests of 


\section{International Journal of Engineering Applied Sciences and Technology, 2019 \\ Vol. 4, Issue 5, ISSN No. 2455-2143, Pages 280-284 \\ Published Online September 2019 in IJEAST (http://www.ijeast.com)}

the ruling class determine how people look at their social conditions, their real existence and their ideas: laws, for example, are not the product of divine reasons, but they are made in a way, which fits the personal interests of the dominant class, that spreads some false ideas in society in order to change the formula of existence. These ideas play a significant role in determining and shaping the ordinary people's mentality. The lower class, in turn, absorbs these ideas and establishes a ground on which they build their satisfactions. Raman Selden explains:

"Marx was arguing that what we call 'culture' is not an independent reality but is inseparable from the historical conditions in which human beings create their material lives; the relations of dominance and subordination (exploitation) which govern the social and economic order of a particular phase of human history will in some sense 'determine' (not' cause') the whole cultural life of the society" (Ibid., p. 25).

Marx also argued that culture served to justify inequality, for the ruling class, or the bourgeoisie, produce a culture that promotes their interests, while repressing the interests of the proletariat. Marx believed that the history human society was the struggle between groups of people with diverging economic interests and thus the economy determined the cultural superstructure of values and ideologies. For this reason, Marx is a considered a 'materialist' as he believes that the economic (material) produces the cultural (ideal). Marxist understanding of culture and ideology, therefore, points at another relevant discourse, materialism which as a doctrine started and developed from Karl Marx and Friedrich Engels. Marx and Engels presented an evolutionary model of societies based on the materialist perspective. They argued that human societies and their cultural institutions (like religion, law, morality, etc.) were the outgrowth of collective economic activity. For Marx, each economic system or "mode of production" in human history contained within it a contradiction that eventually led to its demise and replacement by another, more advanced stage of economic and social life. The contradictions inherent in feudalism, such as the necessity for states ruled by monarchs to trade with other states, thus creating a merchant class, eventually led to the advance of capitalism. Thus, an overarching theoretical assumption of Marx's social is that humans are material things and their social world would be understood as material in its actuality. Therefore, traditional Marxists believe that cultural products were made in the same way as other items of consumption from soap to cigarettes. Unlike previous forms of cultural production where the artist, performer or craft worker retained some control and the product could be said to contain some form of originality, mass production had ensured that artistic and creative input only had value in so far as they function within the capitalist productive process. Moreover, Raymond Williams asserted that culture itself is a productive process, meaning it is responsible for making intangible things that exist in society, like ideas, assumptions, and social relations. The theory of cultural materialism that he developed holds that culture as a productive process is part of the larger process of how a class system is made and remade, and it is connected to the class-based inequalities that pervade society. According to cultural materialism, culture and cultural products play these roles through the promotion and justification of certain values, assumptions, and worldviews within the mainstream and the marginalization of others that do not fit the mainstream mould (consider the way rap music has been routinely vilified as violent by mainstream critics, or how twerking is often framed as a sign that someone is sexually loose or morally deficient, while ballroom dance is held up as "classy" and refined) (https://www.thoughtco.com/cultural-materialism3026168). The theory of Cultural Materialism (emerged as an expansion of Marxist materialism) explains cultural organization which is shaped by ideology within a materialistic framework. Unlike Marxist theory, Cultural materialists like Marvin Harris views both productive (economic) and reproductive (demographic) forces as primary factors that shape society. Cultural materialists view society as being operated by the process of production and reproduction and this becomes the driving force behind all cultural development.

It is in this backdrop that this paper attempts at situating the North East India and ethnic cultures of this region and how due to globalization ethnic cultures are irrevocably converging for the sake of production and reproduction, thus losing their ethnic identity and uniqueness. North East India, comprising of the seven sister states, presents a wide diversity of almost 400 tribal, ethnic and non-ethnic communities, with their distinct culture, language and economy. Social formations in this part of the country are marked by pre-colonial, colonial and post-colonial transformations. One interesting area of transition is from the precolonial royal legitimation to the colonial production of division of culture and economic labour, to the post-colonial distinctiveness of being 'such and such' in terms of self-definition. North East India is the homeland of a large number of ethnic groups who came from different directions at different historical times. These groups belong to different racial stocks, speak different languages, and have varied socio-cultural traditions. In 


\section{International Journal of Engineering Applied Sciences and Technology, 2019 Vol. 4, Issue 5, ISSN No. 2455-2143, Pages 280-284 \\ Published Online September 2019 in IJEAST (http://www.ijeast.com)}

sociology, ethnicity is a concept referring to a shared culture and a way of life. This can be reflected in language, religion, material culture such as clothing and cuisine, and cultural products such as music and art. Ethnicity, unlike race, is not based on biological traits, except in the case of ethnic groups that recognize certain traits as requirements for membership. In other words, the cultural elements that define a particular ethnic group are taught, not inherited. This means that the boundaries between ethnic groups are, to some degree, fluid, allowing for individuals to move between (https://www.thoughtco.com/ethnicity-definition3026311). This can happen, for example, when a child from one ethnic group is adopted into another, or when an individual undergoes a religious conversion. It can also happen through the process of acculturation, whereby members of a native group are forced to adopt the culture and manners of a dominating host group. For the formation of ethnic identity combination of factorscommon descent, socially relevant cultural or physical characteristics, and a set of attitude and behaviours- is necessary. Cultural attributes like distinctive beliefs, institutions, practices, religion, and language often form the bases of identity. To consolidate into an identity the members of an ethnic group must also share ideas, behaviour patterns, feelings, and meaning. They should distinguish themselves (we) from others (they). They should also perceive that they share a common destiny. Thus, culture, backed by some sort of ideology that legitimizes certain kind of beliefs, norms and values, play a significant role in shaping ethnic identity. Culture, which manifests itself in expected behaviour, belief, values, social forms, language, lifestyle, festivals, food habits, dress, and celebration, is, as a product, participate in the process of production and reproduction and becomes the driving force behind the formation of ethnic or any kind of identity.

\section{METHODOLOGY}

Due to globalization there is a cultural diffusion which is the spread of cultural items such as ideas, lifestyle, foods, language and this, although increased cross-cultural contacts, resulted in the degradation of uniqueness of once-isolated communities. In North East India, there are various ethnic groups who have their own unique culture, values and lifestyle which undoubtedly has been greatly affected by the process of convergence. For instance, Pitha, (Assamese: পিঠা pitha, Bengali: পিঠে pithe) which is a type of rice cake, is a marker of Bengali culture and identity (https://en.wikipedia.org/wiki/Pitha). In Assam, pitha is a special class of rice preparation generally made only on special occasions like Bihu. But sadly nowadays, in this age of rapid technological advancement, very few people understand the importance of this food, for they sacrifice this cultural heritage for the sake of pizza and burger, which are made available due to globalization. Here, pitha, as a cultural product, is losing its value for it is not able to participate in the process of production and reproduction, and therefore, is substituted by some foreign products. Through mass media and advertisement, foreign companies (capitalists) have been able to spread some false ideas in society in order to change the formula of existence. These ideas play a significant role in determining and shaping the ordinary people's mentality. The ethnic people, in turn, absorb these ideas and establish a ground on which they build their satisfactions.

Similarly, in the context of Assam, we can notice how the culture of the ruling class (or in the present socio-political scenario the popular culture) becomes the dominant cultural value of ethnic culture. By giving importance only to a certain kind of ideology or beliefs or values, the collective consciousness of a given society is formed. Marx and Engels deal with ideology as a kind of 'false consciousness'. The ruling class maintains the right of spreading some ideas in society. It gives these ideas the form of universality and considers them the only rational ones. Marx's dominant ideology thesis refers to all the false arguments disseminated by the ruling class. The ideas advocated by the ruling class appear as objective facts in order to hide their self-interest. The beliefs of the ruling class may not be recognized as 'ideological'; but the strategies this class uses disguise their self-interest. Cultural icons represent the values and status quo of a particular culture. A 'cultural icon' may be defined as a person or thing regarded as a representative symbol, especially of a culture or movement, perhaps even considered worthy of admiration or respect. It is easily recognized and generally represents an object or idea with great cultural significance to a wide cultural group. Cultural icons, therefore, are determinative factors defining an ethnic identity. However, in the present socio-political and cultural framework of India and especially of Assam, one can observe how the icons of a particular or popular culture are superimposed over some ethnic culture and in this respect ideology plays a significant part, for ideology makes things look normal or acceptable. For instance, whenever we talk about the notion of patriotism or nationalism even in the remotest area of North East, from political point of view, we inevitably bring the name of Bhagat Singh, who is no longer just a name but has transformed into a concept or an idea. While doing so, we forget about Kanaklata Barua, who was an Indian freedom 


\section{International Journal of Engineering Applied Sciences and Technology, 2019 Vol. 4, Issue 5, ISSN No. 2455-2143, Pages 280-284 \\ Published Online September 2019 in IJEAST (http://www.ijeast.com)}

fighter and AISF leader from Assam who was shot dead while leading a procession bearing the National Flag during the Quit India Movement of 1942. During the Quit India Movement Kanaklata joined the Mrityu Bahini, a death squad comprising groups of youth from the Gohpur sub division of Assam. On 20 September 1942, the Bahini decided it would hoist the national flag at the local police station. A procession of unarmed villagers was led by Barua to do so. The police under Rebati Mahan Som the officer in-charge of the police station warned the procession of dire consequences if they proceeded with their plan. Undeterred by the police, the procession continued marching ahead when the police fired upon the procession. Kanaklata was shot and the flag she was carrying with her was taken up by Mukunda Kakoti who too was shot at. Both Kanaklata and Kakoti were killed in the police action. Kanaklata was only 17 years of age at the time of her martyrdom. The Fast Patrol Vessel ICGS Kanak Lata Barua of the Indian Coast Guard, commissioned in 1997, is named after Kanaklata. A life size statue of hers was unveiled at Gauripur in 2011. Her impassioned speech before her death, remains a source of inspiration for many. She laid down her life for the freedom of the country at the age of 17 years. Kanaklata is no more with us, but her sacrifice of her life for the cause of the freedom of our country has remained a great source of inspiration for thousands of Indian women. Her sacrifice can be compared with Rani of Jhansi who sacrificed her life for the cause of India's freedom at the time of Sepoy Mutiny (http://www.assaminfo.com/famous-

people/32/kanaklata-barua.htm).

One can notice as how social media, there are lots of 'stories' or 'memes' about Bhagat Singh that have been spread for the purpose of awakening the feeling of patriotism; even through the broadcast of films, dealing with such martyrs, in popular TV channels reflects how such propaganda shapes the consciousness as well as ideology of people of North East. Moreover, such production of films and TV serials not only help in popularising certain kind of ideas but also this contributes to the process of production and reproduction, for when we see a particular serial the broadcaster or the TV channel authorities earn their material profit. It is, therefore, obvious that they will produce those kinds of serials or films that are consumable by the large section of society. They do not venture into producing films on martyrs like Kanaklata, for this (if allowed to call it as product) is not helping in the process of production.

Another instance where we can see how a particular cultural idiom, when fails to participate in the 'mode of production' and reproduction i.e. fails to become a 'product' of the ruling class face gradual decline. This point can be made explicit by making a reference to the "Manasa Puja', a popular and dominant cultural idiom of the Bengalis, particularly in Assam. Manasa, also Manasa Devi, is a goddess of snakes, worshipped mainly in Bengal and other parts of Northeastern India, chiefly for the prevention and cure of snakebite and also for fertility and prosperity. However, one can notice that this puja has remained confined within Bengali culture and received no nation-wide acknowledgement. On the other hand, Ganesh Chaturthi is celebrated across the country with much pomp, show and splendour because it has been able to become a 'product' through various medium, for instance, through Bollywood films where it is shown how Ganesh Chaturthi is celebrated with much glamour. Although it is difficult to put a date on when people first started celebrating Ganesh Chaturthi, as per historical records, the great Maratha leader Chatrapati Shivaji Maharaja initiated Ganesh Chaturthi celebrations in Maharashtra to promote the spirit of nationalism. Moreover, it was during India's freedom struggle that Lokmanya Tilak changed Ganesh Chaturthi from a private celebration to a grand public festival where people from all castes of the society can come together, pray and be united (https://timesofindia.indiatimes.com/life-

style/events/ganesh-chaturthi-2019-historyimportance-and-rituals-of-vinayaka-

chavithi/articleshow/70877033.cms). So one can see how this aspect of Marathi culture (if allowed to term this way), through various methods of promotion, becomes a product of the ruling class and thereby is consumed or celebrated across India nowadays. In opposition to this, Manasha Puja remained confined within Bengali culture, for it has not been promoted widely through media like Television and through films. So nowadays, even in Silchar, it has become a trend to celebrate Ganesh Chaturthi, for it has been inflicted into the consciousness of the people of Barak Valley and thus, constitutes the ideology of Bengali culture. Here, it becomes apparent as to how ideology, which is creates 'false consciousness', sanctions or legitimizes certain beliefs, values and cultural norms (which are mostly the products of the ruling class) as normal or standard. At the same time, it posits some sort of threat to ethnic culture and identity, for if ethnic culture fails to participate in the mode of production (i.e. to become the culture of the ruling class), its position is, therefore, always contested and debatable.

Taking into consideration the present socio-political scenario of the country, one can observe that ethnic culture and language is jeopardized, because of the 'imposition' of Hindi as the lingua franca. For instance, tweeting in Hindi, Union Home Minister Amit Shah said: "Today, if one language can do the work of uniting the 


\section{International Journal of Engineering Applied Sciences and Technology, 2019 \\ Vol. 4, Issue 5, ISSN No. 2455-2143, Pages 280-284 \\ Published Online September 2019 in IJEAST (http://www.ijeast.com)}

country, then it is the most spoken language, Hindi. There is so much influence of English on us that we cannot talk in Hindi without its help" (https://indianexpress.com/article/opinion/columns/ hindi-imposition-one-nation-one-language-

$6011348 /)$. Such remarks devalue the importance of ethnic language, for language is an essential aspect defining ethnic identity. For a long period of time, Hindi as a language has transformed into a product due to repeated use this language in Bollywood films and TV serials, and it is through this medium of entertainment that people of different parts of India come to learn this language. While the ethnic language like Bengali does not get the chance exposure as done by Hindi, although in Tollywood, Bengali is used as a prime language, but products of Tollywood are consumed by few people and it does not get the nation-wide popularity. Thus, Bengali language contributes very little in the mode of production, and therefore, is not a language spoken by all. An example can be drawn from Silchar where the official staffs (who are originally Bengali) of many institutions prefer to talk in Hindi, even with Bengalis. It can be inferred here that Hindi, through various modes of production, becomes the language of the ruling class and this has allowed it to shape the ideology of non-Hindi speaking people, thus asserting its supremacy.

\section{CONCLUSION}

Thus, from above discussion it becomes apparent that ethnic culture and identity, in order to survive in this present globalised era as well as in an age of technological advancement, has to participate in the process of production and reproduction, failing which, their uniqueness as well as richness will face hurdles in the days to come, for the material interests of the dominant social class determine how people see human existence, individual and collective. Due to rapid convergence of cultures, the ethnic identity of various groups of people, especially of North East India, are losing their uniqueness and therefore, the only possible way to survive or preserve their distinctiveness is to participate in the modes of production and thereby they would be able to form ideology which, although a 'false consciousness', I think, is a survival tactic.

\section{REFERENCE}

1) “Ganesh Chaturthi 2019: History, Importance and Rituals of Vinayaka Chavithi" Times of India, Sep 2, 2019, 08:42 IST, https://timesofindia.indiatimes.com/lifestyle/events/ganesh-chaturthi-2019-historyimportance-and-rituals-of-vinayakachavithi/articleshow/70877033.cms.
2) "Kanaklata Barua". Assam Info, http://www.assaminfo.com/famouspeople/32/kanaklata-barua.htm.

3) Cole, Nicki Lisa. "Theories of Ideology: The Concept and Its Relationship to Marxist Theory". ThoughtCo., July 03, 2019, https://www.thoughtco.com/ideology-definition$\underline{3026356 .}$.

4) Costello, Paul. (1979). "Ideology: Ideological Practice \& Cultural Criticism". TheoreticalReview No.10, https://www.marxists.org/history/erol/periodicals/th eoretical-review/19791002.htm.

5) Crossman, Ashley. "Definition of Cultural Materialism". ThoughtCo., August 27, 2018, https://www.thoughtco.com/cultural-materialism3026168.

6) Crossman, Ashley. "Ethnicity Definition in Sociology". ThoughtCo., September 30, 2019, https://www.thoughtco.com/ethnicity-definition3026311.

7) Dechamma, Sowmya. "Idea of one country, one language was bequeathed to us by colonialists". The Indian Express, September 20, 2019 11:13:47 am,

https://indianexpress.com/article/opinion/columns/ hindi-imposition-one-nation-one-language6011348/.

8) Griffin, Roger. (2006). "Ideology and culture". Journal of Political Ideologies. 11.10.1080/13569310500395974. https://www.researchgate.net/publication/26286153 9_Ideology_and_culture.

9) Jaggi, Ruchi. (2015). "Culture and Ideology". https://www.researchgate.net/publication/28200106 7_Culture_and_Ideology.

10) Shelden, Raman, Widdowson Peter, Peter Brooker. (2005). A Reader's Guide to Contemporary Literary Theory, 5th ed. Pearson Education Limited,. Soft.

11) Taha, Dr. Ahmad, Dr. Abeer Zahra, Samer Alkhaoli. (2008). "The Marxist Approach to Ideology: Marx and Hegel". Tishreen University Journal for Research and Scientific Studies - Arts and Humanities Series Vol. (30) No. (2).

12) Williams, Raymond. (1977). Marxism and Literature. Oxford University Press. 